\title{
咀嚼機能の訓練効果
}

\author{
柿谷幸男, 中村早江, 清水真知男, 山内六男, 長澤 亨 \\ 朝日大学歯学部歯科補綴学第一講座 (主任：長澤 亨教授) \\ 〔受付: 平成 6 年 4 月 8 日]
}

\section{Effect of Chewing Training on Masticatory Function}

\author{
Yukio Kakitani, Sae Nakamura, Machio Shimizu, Mutsuo Yamauchi and Tooru Nagasawa \\ Department of Removable Partial Denture Prosthodontics, Asahi University School of Dentistry \\ (Director: Prof. Tooru Nagasawa) \\ [Received: April 8, 1994]
}

Key Words: chewing training, hard chewing gum, EMG, mandibular movement

\begin{abstract}
We examined the changes of masticatory function by chewing training using hard chewing gum (gum).
Ten adult males were requested to chew hard gum for 10 minutes after each mealfor four weeks. EMG and mandibular movement during gum chewing and masticatory performance were recorded.

The burst duration and interval of EMG were significantly shotened by training. The burst duration of EMG did not recover pre-training level after the end of training for two weeks. Nuscle activity and masticatory performance were not influenced by training.

The maximal vertical, antero-posterior and lateral displacement of mandible during gum chewing were not affected by training. The maximal opening and closing velocities tended to be increased bytraining. Closing, occlusal and openingphase and cycle time were significantly shortened by training.

These results suggested that the masti-catory muscle power was promptly produced and not increased by chewing training.

抄録 チューインガムを用いた咀嚼訓練が咀嚼機能に及ぼす影響について検討した.

市販の強化ガムを毎食後 10 分間， 4 週間にわたって咬ませた。訓練開始 $1 ， 2 ， 3 ， 4$ 週間後と訓練終了 2 週後までの間の咀嚼時の咬筋 $\mathrm{EM} \mathrm{G}$ ，下顎運動および咀嚼值を記録した。

$\mathrm{EMG}$ 持続時間と間隔は咀嚼訓練により有意に短縮した。また筋放電持続時間は訓練停止 2 週間後も元 の值に戻らなかった。筋活動量ならびに咀嚼值は訓練の影響を受けなかった。

下顎運動の移動量パラメータは咀嚼訓練の影響を受けなかった。開，閉口相，咬合相，咀嚼周期などの 時間パラメータは訓練により短縮した。

これらの結果は咀嚼訓練により筋のパワーを迅速に引き出せることを意味している。しかし，効率よく 筋が働いたとはいえない.
\end{abstract}

連絡先：干 501-02＼cjkstart岐阜県本巣郡穂積町大字穂積 1851-1 


\section{I. 緒言}

近年, 食生活様相は変化し，一般に硬いものより軟ら かい食物が好まれるようになった．軟らかい食物では強 い咀嚼力は必要とせず, また咀嚼回数も少なくなる. 軟 らかい食物を摂取していると顎骨の発育がバランスょく 行われなくなる ${ }^{1)}$.船越 ${ }^{2}$ はラットに固形食と粉末食を 与え, 粉末食飼育ラットは学習効果が現れにくいことを 報告している．このように咀嚼力ならびに咀嚼回数の不 足が生体に与える影響は大きく，この対策の一つとして 訓練用にチューインガム（ガム）を咬ませることにより 咀嚼力を増強させる試みがなされている ${ }^{31}$ 。

小児においてはガム咀嚼訓練により，咬合力ならびに 咬みしめ時の筋活動が有意に増加することが報告されて いる ${ }^{4)}$.しかし，成人においてはガム咀嚼訓練により咀 嚼能率が向上するという報告 ${ }^{5)}$ と, 変化しないという報 告 ${ }^{6}$ があるなどはっきりしていない。さらに，咀嚼訓練 が下顎運動ならびに咀嚼筋 EMGにどのような影響を及 ぼすかについて検討した報告は認められない.

そこで今回，われわれは天然歯列を有する成人男子に 市販のガムによる咀嚼訓練が下顎運動, EMGおよび咀 嚼能率にどのような影響を及ぼすかについて検討を行っ たので，その結果について報告する.

\section{II. 実験材料および方法}

\section{1. 被験者}

顎口腔系に異常を認めない個性正常咬合を有する若い 男性 10名（年齢22-25歳，平均年齢 23.5 歳）を被験者と した。

\section{2. 咀嚼訓練用ガム}

咀嚼訓練には市販の強化ガム（ロッテ社製トレーニン グガム）を用いた。強化ガムは, 縦 $13 \mathrm{~mm}$, 横 $33 \mathrm{~mm}$, 厚さ $3 \mathrm{~mm}$, 重さ $2.0 \mathrm{~g}$ で甘味料 (パラチノース) ”香 料などが含まれている．これを 1 日 3 回，毎食後に 10 分間ずつ 4 週間咬ませた。また, EMGならびに下顎運 動測定時の試験食品には糖分や香料を含まないロッテ中 央研究所製の試作ガムを用いた.

強化ガム, 試作ガムおよび市販の一般ガム（ロッテ社 製グリーンガム) の咀嚼に伴う粘性の变化を粘度計（島 津社製 flow tester, CFT-500）を用いて測定した結果を図 1 に示す.なお，本研究ではガムの粘度を硬さと表現し た. 強化ガムは, 市販ガムを 1 分間咀嚼した場合の硬さ よりも大きい值を示し, 咀嚼開始 1 分後から 5 分後まで の硬さの変化も小さく安定していた．また，実際に強化

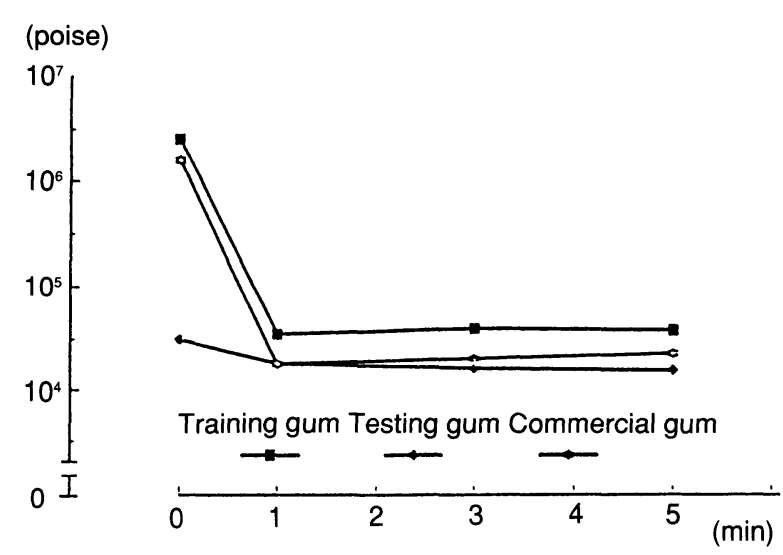

図 1 各種ガムの咀嚼に伴う粘性の変化

ガムを被験者に咀嚼させた場合かなり咬みごたえがある と述べており，咀嚼訓練の実験に十分適用できると思わ れた。試作ガムはそれより多少軟らかく，咀嚼に伴う変 化は小さかった。

\section{EMGならびに下顎運動の記録，分析}

被験者をフランクフルト平面と床面を平行になるよう 歯科用治療椅子に座らせ, 試作ガムを 2 分間以上咬ませ てから実験に供した。

E M G 記録はポリグラフ（日本光電社, RM-6000）を 用い，両側咬筋中央部から表面電極により双極誘導し データレコーダに収録した。下顎運動は Mandibular kinesiograph (Myo-tronics Res., K5AR)により EMG と同 時にデータレコーダに収録した。記録したデータは記録 計（日本光電社製 WS6826）により再生後 E M Gから筋 放電時持続時間，筋放電間隔の時間パラメータと筋活動 量を，下顎運動からは移動量パラメータ（最大上下移動 距離, 前後移動距離, 側方移動距離), 速度パラメー夕 (最大開口速度, 閉口速度), 時間パラメー夕（閉口，咬 合，開口の各相と咀嚼周期）を 20 ストロークについて 計測し，1ストロークあたりの平均值を求めた.

\section{4. 咀嚼值の測定}

Manly ${ }^{8)}$ の方法に従い, ピーナツ $3 \mathrm{~g}$ を咀嚼側を指 定しないで自由に20回咀嚼後ビーカーにはきださせ， これを 5 回繰り返す.ついで10メッシュの笁でこし残 つたものの乾燥後重量を計測し， $3 \mathrm{~g}$ の 5 回， $15 \mathrm{~g}$ に対 する通過量の百分率を咀嚼値とした。

\section{5. 計測時期}

E M G, 下顎運動および咀嚼值の測定は咀嚼訓練前, 開始 1 週後, 2 週後, 3 週後, 4 週後, 訓練停止 1 週後, 2 週後の計 7 回とした. 


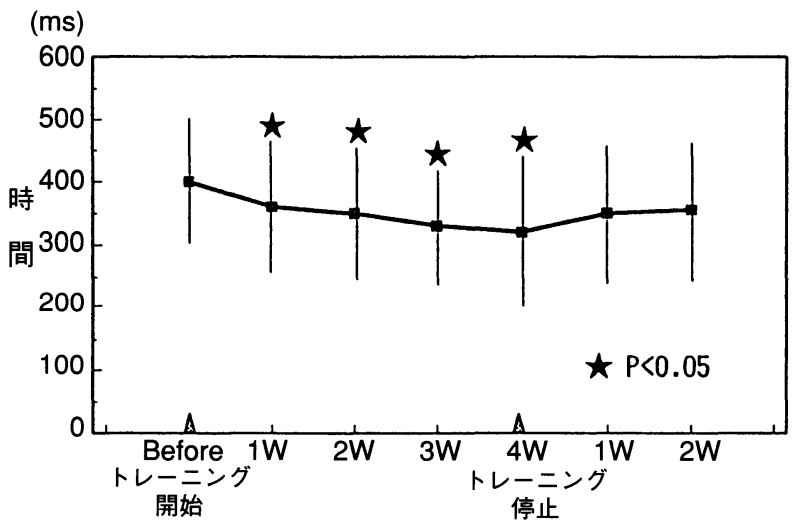

図 2 咀嚼訓練による筋放電間隔の変化

(uV.s)

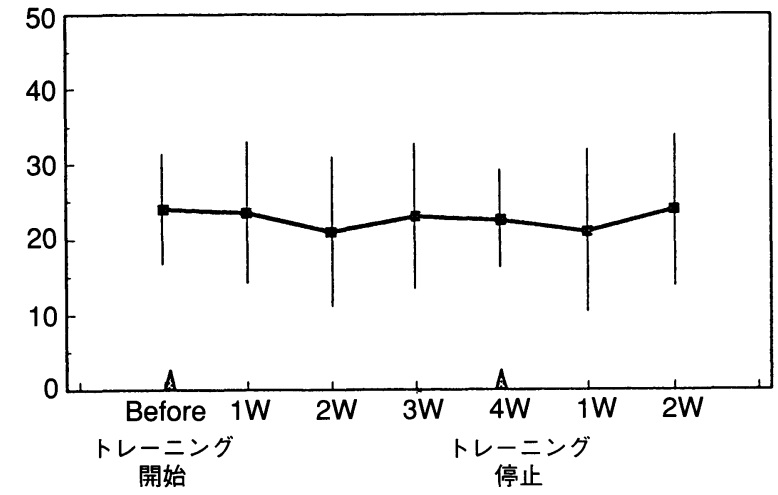

図 3 咀嚼訓練による咬筋活動量の変化

\section{III. 実験結果}

\section{1. $E M G$}

時間的パラメータの筋放電持続時間は訓練開始 1 週後 に有意に短縮し，4 週後に最も小さな值を示した。訓練 停止 2 週後は訓練前の值に近づく傾向はあるがまだ有意 に短縮したままであった。一方，筋放電間隔は図 2 に示 すように訓練開始 1 週後より有意に短縮し,

4 週後に最も小さな值を示したが，訓練停止により速や かに訓練前の值に戻った.

この間，筋活動量には変化が認められなかった（図 $3)$.

\section{2. 下顎運動}

下顎の移動量パラメータには咀嚼訓練による変化は認 められなかった。速度パラメー夕にも変化はなかったが,

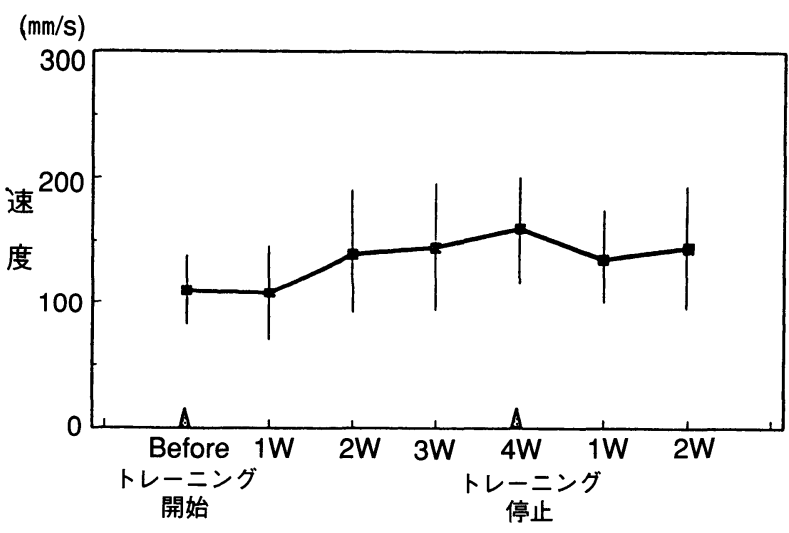

図 4 咀嚼訓練による最大開口速度の変化

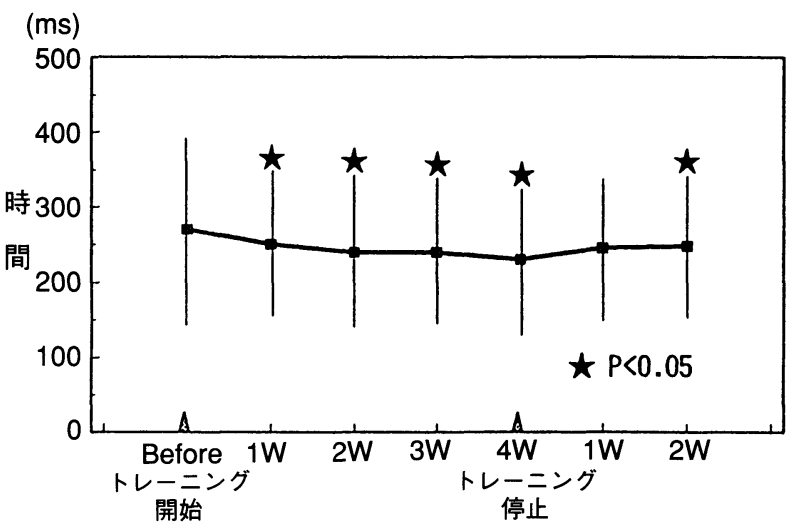

図 5 咀嚼訓練による閉口相時間の変化

咀嚼訓練により増加する傾向が認められた（図 4 ）。

一方，EMGに認められたように時間パラメー夕は咀 嚼訓練によりいずれも短縮した。閉口相時間（図 5 ), 咬合相時間（図 6 ), 開口相時間（図 7 ）は訓練開始 $1-2$ 週後に有意に短縮し, 訓練停止後は訓練前の值に 徐々に近づく傾向を示した，閉口相時間については，訓 練停止 2 週後もなお訓練前の値とは有意差があった.

これら各相の合計時間である咀嚼周期は，図 8 に示す ように当然訓練による短縮は 1 週後より認められ, 訓練 停止 2 週後は訓練前の值に近づいたが，なお訓練前より 有意に短縮傾向にあった。

\section{3 , 咀嚼值}

咀嚼訓練による咀嚼值の変化は認められなかった。 


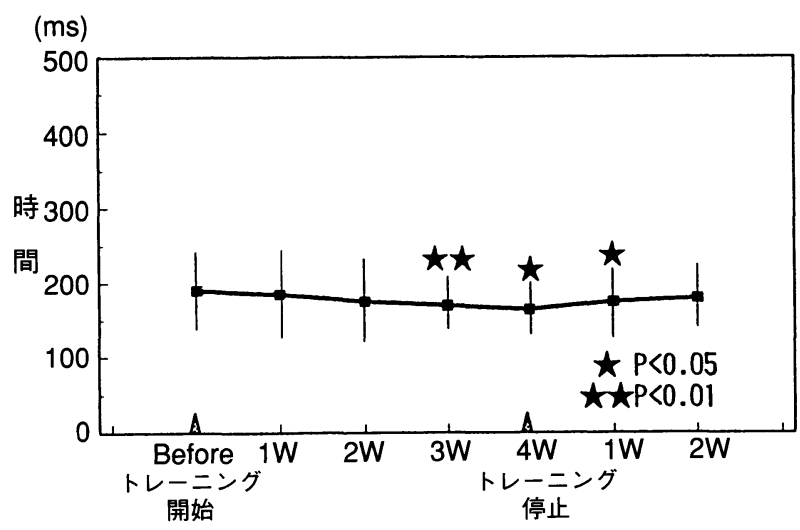

図 6 咀嚼訓練による咬合相時間の変化

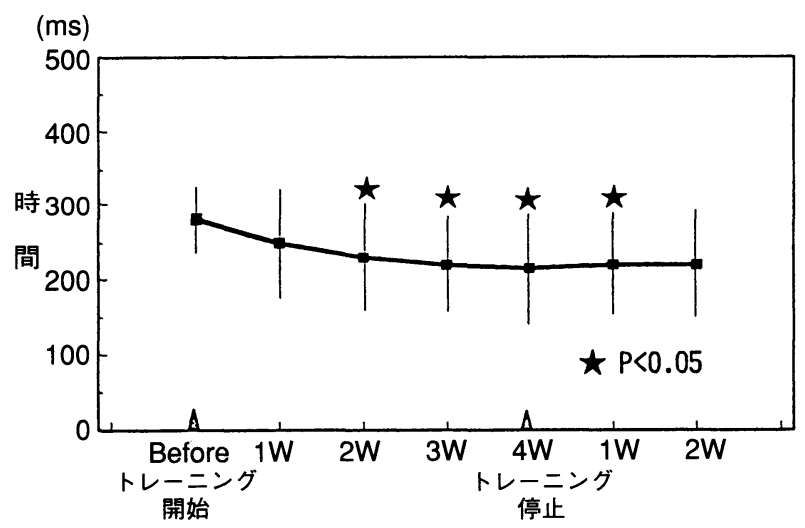

図 7 咀嚼訓練による開口相時間の変化

\section{IV. 考察}

咀嚼訓練用食品として過去種々のものが用いられてき たが，本研究では成人が比較的慣れていると思われるチ ユーインガムを用いた. 強化ガムは通常のガムに比べて 硬く, 本研究の目的に十分合致するものと思われた。な お，このガムは甘味料として低齟蝕原性のパラチノース 7) が用いてあるため, カロリー摂取過多あるいは齨蝕に 対する心配はない.

訓練のために毎日ガムを咬ませる時間は研究者によっ て異なり，約 10 分 $^{4)}$ から 1 時間以上 ${ }^{3,6)}$ と幅がある. 長く咬ませた方が訓練になるかもしれないが，1日 1 時 間以上咬ませるのは現実には困難なため本研究では毎食 後10分，1日で 30 分咬ませることにした。また，訓練 期間は過去の研究を参考に 4 週間とし, 訓練停止 2 週後

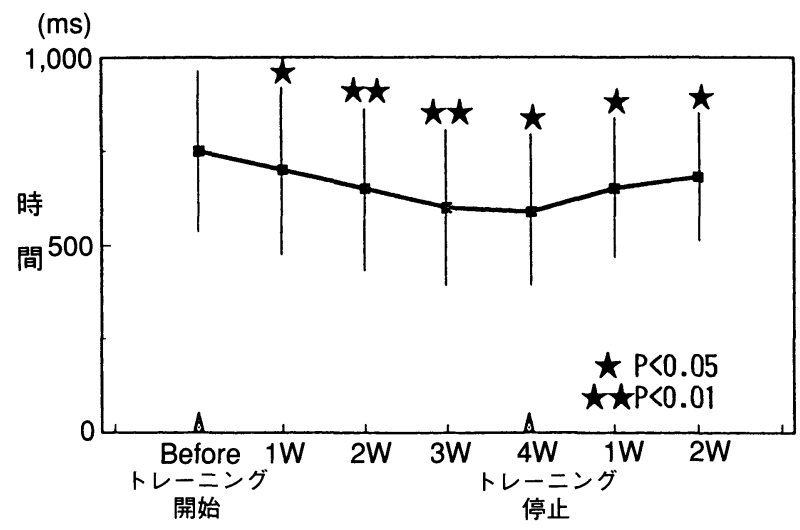

図 8 咀嚼訓練による咀嚼周期の変化

まで訓練効果の持続について検討した.

実験の結果, EMG, 下顎運動ともに時間的パラメー 夕は訓練によって短縮したが，咬筋の筋活動や咀嚼值に は有意な変化はみられなかった．河村ら ${ }^{5)}$ は成人におい て咀嚼訓練により咀嚼能率が向上すると報告している. この差は咀嚼訓練の時間，期間の他に訓練用の食品の差 などによるものであろう。事実, 1 力月の咀嚼訓練で咀

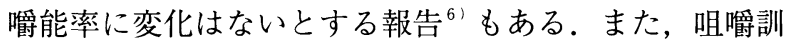
練により咬合力が増加したとする報告 ${ }^{5}$.9) もあるが，今 回の実験では咀嚼中の筋活動の増加は認められなかっ た。咀嚼は半ば反射的に行われるもので，咀嚼時に発揮 される力はすでに各個人で獲得されており，今回程度の 訓練で変化しなかったのは当然かもしれない.

咀嚼訓練により変化したパラメータも訓練停止により もとのレベルの戻る傾向を示した。

河村 $5^{5)}$ ，Brekhus $ら^{9)}$ も訓練停止 2 週間で元に戻るこ とを報告しており, 今回行った程度の咀嚼訓練では持続 的な訓練効果はないといえよう.

\section{V. 総 括}

チューインガムによる咀嚼訓練を 4 週間にわたって行 い, $\mathrm{EM} \mathrm{G}$ と下顎運動に与える影響を検討し次の結果を 得た。

1. E M G, 下顎運動ともに時間パラメー夕は短縮し た。

2. $\mathrm{EMG}$ 活動量，下顎運動の速度ならびに移動量パラ メー夕には変化がみられなかった。

3. 訓練により変化したパラメータは, 訓練停止 2 週間 後には元の值に戻る傾向を示したが，まだ訓練効果 
の持続するパラメータもあった。

4. 成人では咀嚼訓練効果は持続しないと結論できる.

以上の結果，咀嚼訓練により筋力を迅速に発揮できる ようになるといえる。

\section{文献}

1) Watt, D.G. and Williams, H.M.; The effects of the physical consistency of food on the growth and development of the mandible and maxilla of the rat. Am J Orthod, 72: 895-928, 1951.

2) 船越正也：咀嚼と脳，咀嚼システム入門（文部省特 定研究「咀嚼システムの基礎的研究」総括班編), 風人社, 東京, 211-224, 1987.

3) Ingervall, B.and Bitsanis, E: A pilot study of the effect of masticatory muscle training on facial growth in long-face children. Eur J Orthod, 9: 15-23, 1987.

4) 平木健史：上顎前突を呈する児童の咬合力と閉口筋 活動に関する研究：チューインガムによる咀嚼訓練 の効果, 阪大歯学誌, 36:389-414, 1991.

5) 河村洋二郎, 堀尾 強: 咀嚼機能強化食品 による咀 嚼訓練の効果，歯基礎誌，31:281-290, 1989.

6) Tzakis, G.M., Kiliaridis, S. and Carlsson, G.E.: Effect of chewing traininig on masticatory efficiency. Acta Odontol Scand, 47: 355-360, 1989.

7) 池田 正：歯科領域からみた甘味料一う蝕予防の立 場から一, 臨床栄養, 71: 736-741, 1987.

8) Manly, R.S. and Braley, L.C.: Masticatory performance and efficiency. J Dent Res 39:448-462, 1950.

9) Brekhus, P.J., Armstrong, W.D. and Simon W.J.: Stimulation of the muscles of mastication. J Dent Res, 20: 87-92, 1941. 